\title{
Leadership Needs in the Hungarian Social Cooperatives. Results of a Survey
}

\author{
Sándor Bozsik¹, Katalin Lipták², Zoltán Musinszki³, Judit Szemán \\ ${ }^{1,2,3,4} \mathrm{Ph}$. D, Associate Professor, Faculty of Economics, University of Miskolc, Hungary
}

\begin{abstract}
The social cooperatives have a very important function in a peripheral area, they can create jobs for unemployed or disabled people in order to solve the unemployment problem in this area. Of course they can create with the necessary flexibility and innovation skills for rural areas and help to maintain the social peace to provide work with the less competitive part of the rural population (Bartha \& Bereczk, 2018). However, the management of this enterprises faces several dilemmas how can build up an effective control system of a social enterprises in CentralEurope. Our research group has a long-term research project to help the social cooperative management in the daily operation based on a well-suited Balanced Scorecard Model to the specific needs of these organisation. A questionnaire survey has been made asking the social cooperative managers about the administration and management problems of their enterprises. According to our survey, the major problem of social cooperative is the quality of available labour force. So, the Human Resource management and how its tools can be effectively adapted to the social cooperatives has got a vital importance. The future aim of our research program is to develop a report system and a ratio analysis tool to help the work of social cooperative managers.
\end{abstract}

Keywords: social economy, social cooperatives, Balanced Scorecard, Human Resource Management

\section{Introduction}

In the 19th century the solidarity through associations, by combining economic, political and social goals, paved the way for a social economy that includes many organizations with noncapitalist status (cooperatives, associations, aid unions). But despite the economic weight of such organizations in much of the 20th century, their real strength still did not arise (Laville, 2010a). Today, in the most widespread economic model, three economic sectors operate in parallel. The first sector, which is characterized as economically active, the private sector, includes business enterprises and companies, their main goal is to make a profit. The second sector, which is not engaged in business activities and is therefore considered to be economically inactive, is the public sector, whose main task is to operate the public administration (Musinszki and Süveges, 2018). Organizations in the third sector are extremely diverse: the solidarity economy, which brings together social enterprises and economically active non-profit organizations, and the community economy, which includes charitable organizations. (G.Fekete, 2017) 
The solidarity economy seeks to change the entire social and economic system and strengthens the various paradigms of development based on the principles of the solidarity economy (Kawano et al., 2010). No help is expected from the primary economy (neither from the market sector nor from budget organizations forced to lay off staff) to reduce long-term unemployment. A possible way to do this is to support the employment initiatives of non-profit organizations and to create jobs outside the mainstream of the labour market (Mückenberger, 2018). The need for innovative solutions to existing social problems has been steadily increasing, as the state has not been able to provide a solution in all cases (Laville, 2010b). According to the European interpretation, the term social economy means a set of organizations interpreted more broadly than the non-profit sector (Salamon \& Anheier, 1997).

Social enterprises are the cornerstones of a solidarity economy (Borzaga \& Defourny, 2004; Defourny \& Nyssens, 2012). Social enterprises produce the market product or service in an entrepreneurial and innovative way, place the social impact before making a profit, return the profit for social purposes, operate with open and responsible management, and involve employees in their decisions (Nyssens \& Defourny, 2008). There are many social enterprises in Europe in the central regions, in smart cities. In the peripheral areas are not too much social enterprises but there would be a need for social enterprises in the peripheries. The social enterprises can be a social cooperatives, associations or foundations.

In this study we will analyse only the social cooperatives, because this is the most important type of social enterprises in Hungary. According to our hypothesis the social cooperatives have some difficulties, the most significant difficult is finding and retaining human resources. After summarising the regulatory framework of the social cooperatives, a survey is interpreted, which was made to detect the most crucial managerial problems of social enterprises. Through a graphical presentation the major findings are introduced and our final chapter summarises our main conclusions.

\section{Social enterprises in Hungary}

Social enterprise does not have a uniform and widely accepted definition in Hungary, nor is there a uniform legal framework. There is no separate law or legal form for social enterprises in Hungary. The legal framework is provided by the laws of various non-profit organizations, volunteering and social cooperatives, and in particular the new civil law of 2011. It is also common to use the term without a definition (G. Fekete et al., 2014a). The concept of social enterprise appeared in the 1990s, and then became better known in Hungary in the 2010s. The three main criteria for non-profit organizations as interpreted by Kuti (1998) are: (1) the prohibition of profit distribution; (2) operational autonomy and organizational separation from the government sector; (3) institutionalization as an independent legal entity. In addition to these three key criteria, Kuti (1998) lists additional elements such as the presence of volunteering; charity; the role of civic initiatives; the service of the public good, that is to say, the pursuit of an activity which serves, directly or indirectly, the interests of society as a whole or of the wider community; (3) exclusion of party political activity; and (4) the exclusion of credit activity in a church organization. The most important feature of the concept of the nonprofit sector is the prohibition on profit distribution. Social enterprises play an important role in the labour market integration of disadvantaged groups and in education, social care and other special services. One of the basic goals of social enterprises is to serve a priority group of the community or people. In the same approach, the specificity of social enterprises is the desire to promote social responsibility at the local level. Social enterprises are the results of a collective 
dynamic involving people belonging to a community or group that shares a well-defined need or goal; this collective dimension is one way or another, but it must persist over time, even if the importance of leadership is unavoidable. (Kuti, 1998)

The public sector has not used the concept of social enterprise in official documents for a long time. The focus was on the social economy, in particular support for social cooperatives in ducks through EU co-financed programs. However, the term Hungarian social enterprise is already used in the new Hungarian Partnership Agreement 2014-2020, and in 2015 the first policy definition was used in connection with a state aid program. The public sector is interested in the explicit support of social enterprise, and some local government initiatives also consider themselves to be social enterprise.(G. Fekete et al., 2014b)

Social cooperatives are the only legally codified special form of social enterprises in Hungary. According to Németh, social cooperatives are autonomous communities that aim to meet the needs arising from the social and economic division of labour (Németh, 2012). They are organized around three principles: caring for others and the community, taking responsibility, and solidarity. In Hungary, Act X of 2006 established social cooperatives as a special form of cooperatives. With regard to the definition of the social goal and the target group affected by the activities of social cooperatives, the law is permissible in international comparison.

Social enterprises have a number of problems: they tend to rely heavily on external, state subsidies, which are rather unpredictable, not normative but only occasional, often too bureaucratic, inflexible, not based on local needs and scarce. Support programs are often criticized for their lack of transparency and communication, political bias, and more support for pro-state organizations, leading to sector polarization. According to G. Fekete (2014), one of the problems of the sector is the lack of supporting infrastructure. Another problem is low purchasing power and the inadequacy of potential markets, especially in disadvantaged regions where social entrepreneurship would be particularly relevant. Business investors are generally not seen as a viable alternative - neither investors nor organizations. Although market-oriented social enterprises with social goals and sustainable business models have emerged recently, they are still relatively small and not visible enough to the general public. (G. Fekete et al., 2014a)

In Hungary, many factors hindering the development of social enterprises can be identified. The lack of a widely accepted definition is a problem; ignorance of the concept; lack of uniform legislation or long-term strategy; dependence on external, mainly public funding, its unpredictability, bureaucracy, inflexibility and scarcity; low purchasing power of potential consumers, insufficient markets, especially in disadvantaged regions; and the lack of entrepreneurial and leadership skills of social entrepreneurs (G. Fekete et al., 2017).

In our research, we identified 5 types of social enterprises in Hungary:

1. Public service social enterprises provide services that were previously state or municipal tasks. For this reason, they receive state support on a normative basis, but their operation is also financed from market income. These businesses operate primarily in the social and utility sectors.

2. Entrepreneurial NGOs: Classical NGOs (mainly foundations, associations) working for social, cultural and environmental purposes have also started to carry out business activities in recent years in order to maintain their organization and achieve their goals. Their economic activity is aimed at supplementing private donations and public tender resources. 
3. Some NGOs can be considered as social enterprises for labour market integration, often in the form of a non-profit legal form with a bottom-up approach. However, the term labour market integration social enterprise is not explicitly used in Hungary. Among their target groups are various disadvantaged groups, e.g. young people, women, Roma, the low-educated and the poor.

4. Community enterprises aiming at local development implement integrated, multifunctional local economic programs, usually implemented directly or indirectly under the direct control of local governments. The focus is on the production of a local product or an activity for the operation and development of the settlement. They operate mainly in rural areas where there is a lack of entrepreneurship, linked to agriculture and missing services.

5. Social start-ups: In the operation of the enterprise, the economic activity and the business are the determining one, but it is driven by some ethical goal arising from social responsibility. The social goal has a direct impact on economic activity and serves a shift towards a more solidarity-based and environmentally sustainable economy. Profit orientation is not ruled out. (G. Fekete et al., 2018)

\section{Regulatory framework of social cooperatives}

The social cooperatives can be established by the Act on Cooperatives (2006/X) in Hungary. The special rules of social cooperatives are determined by the government order 141/2016. An application was written out for supporting the creating social cooperatives called „Focus programme for promoting social cooperatives with local government membership". (OFA, 2016)

Most of the social cooperatives are established to utilise the opportunities offered by the Focus programme. The condition of this Application was that at least two of members should be earlier public worker, and the employees should be former unemployed, student or pupil (Katonáné Kovács et al., 2017). The requirements of the Application related to the Human Resource Management were the followings:

- The social cooperatives should ensure new and long-lasting employment up to 2020 for those, who were former unemployed, or public workers.

- The social cooperatives can apply for a subsidy up to 7,5 million forint/annum/person to cover the gross wage and social contribution tax. In the first year the sum of subsidy can reach the $100 \%$ of this amount, in the second year it decreased to $90 \%$, in the third year to $80 \%$.

- One project manager can receive a monthly payment up to the twice of the minimal wage + its contribution tax and travelling cost from this subsidy.

- At least two members of the social cooperatives should take part a social manager training and annually at least 6 members should attend in a two-day long community building training.

- Semi-annually the social cooperatives can require advisors from one of the following areas (Labour Law, Finance, Sustainability or Marketing Management), and annually it can be supplied with consultant in field of organisational development or rationalisation or Human Resources Management. These external experts and the trainings are financed by the supervisory authority called OFA (National Employment Fund). 
- Furthermore, it can be applied for additional and optional advisory support like technical advisory work for implementing investments and equipment purchase, commercial activities.

To monitor the activity of the social cooperatives the supervisory authority also requires regular reports. Some of them are also related to the Human Resource Management. These are the followings:

1. Monthly report on the number of employment (in- and outgoing staff)

2. Quarterly report on the professional progress of employee taking part in various development programmes.

3. Quarterly report on involvement of external advisors (goal, task, evaluation of success)

\section{Questionnaire on the managerial problems of Hungarian social cooperatives}

The authors of this article are trainers of a further education training programme for social cooperative managers jointly organized by the Faculty of Economics of the University of Miskolc (GTK) and the supervising organization of social cooperatives - called National Employment Non-Profit Limited Company (OFA).

In the frame of this training programme we were able to meet several managers of social cooperatives. A questionnaire was prepared for them to ask their opinions about the economic and managerial problems of social cooperatives. The questionnaire was filled in by 73 people till the writing of this paper

The survey was made between Spring and Summer of 2020, the survey contains 15 questions, from which 5 questions were devoted to the characteristics of the respondents (sex, age, education, labour time, working experience), 3 questions dealt with the circumstances of the social cooperatives (geographical area, industrial sector, number of employments) and 6 complex questions were taken to describe the managerial and administrative problems.

The distribution of the respondents was the following:

Table 1: The grouping of respondents by various aspects

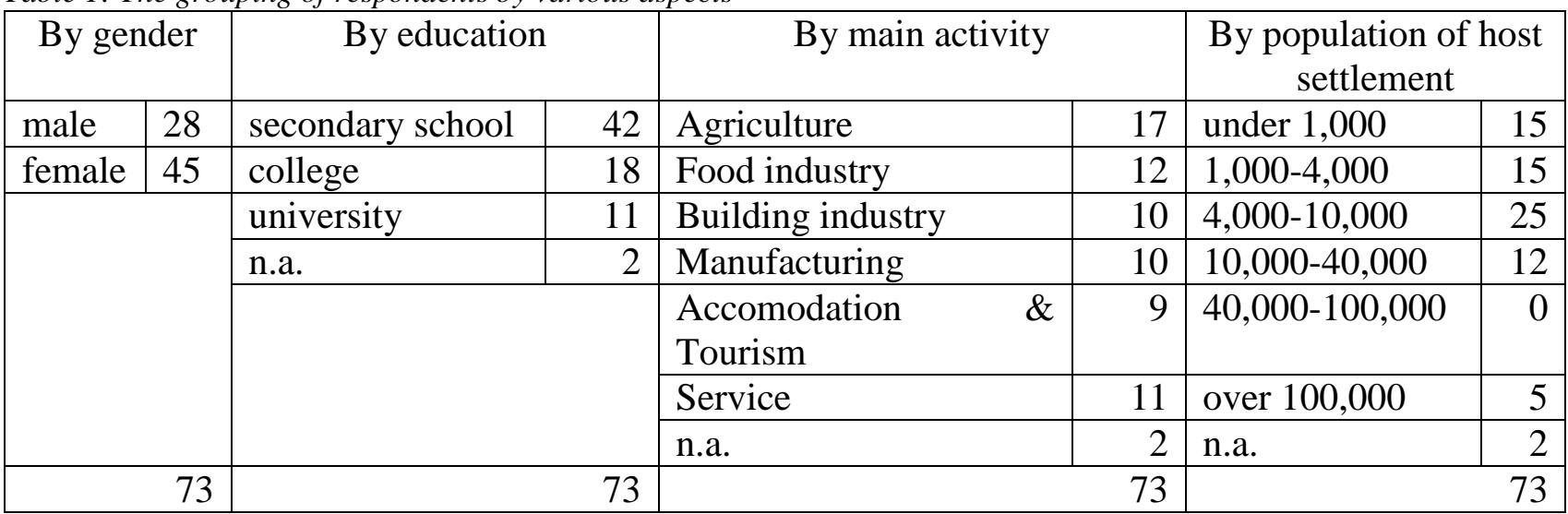

Source: (Szemán et al., 2020)

Majority of the respondents came from the less developed part of Hungary mirrored the fact, that the social cooperative mission is to help the rural, poor region. From Southern Plain 40\%, from South Transdanubia 19\%, from Northern Plain 17\% and from Northern Hungary 14\%. The rest represents $10 \%$. 
Furthermore, we have made 8 deep interviews with social cooperative managers, to highlight the reasons behind the questionnaire output. In the analysis part our conclusions were based on the interviewers' view.

\section{Managerial problems of social cooperative}

The question was the following: "Please rank by importance of the following problems in the management of social cooperative" 73 social cooperative managers were asked from different regions of Hungary.

Sixteen potential sources of managerial problems were listed grouped in three categories, and the respondents were asked to rank the problems by their seriousness in the economic management of their organisation. The answers are presented in figure 1.

Figure 1: Significance of labour quality issues in the management of social cooperatives

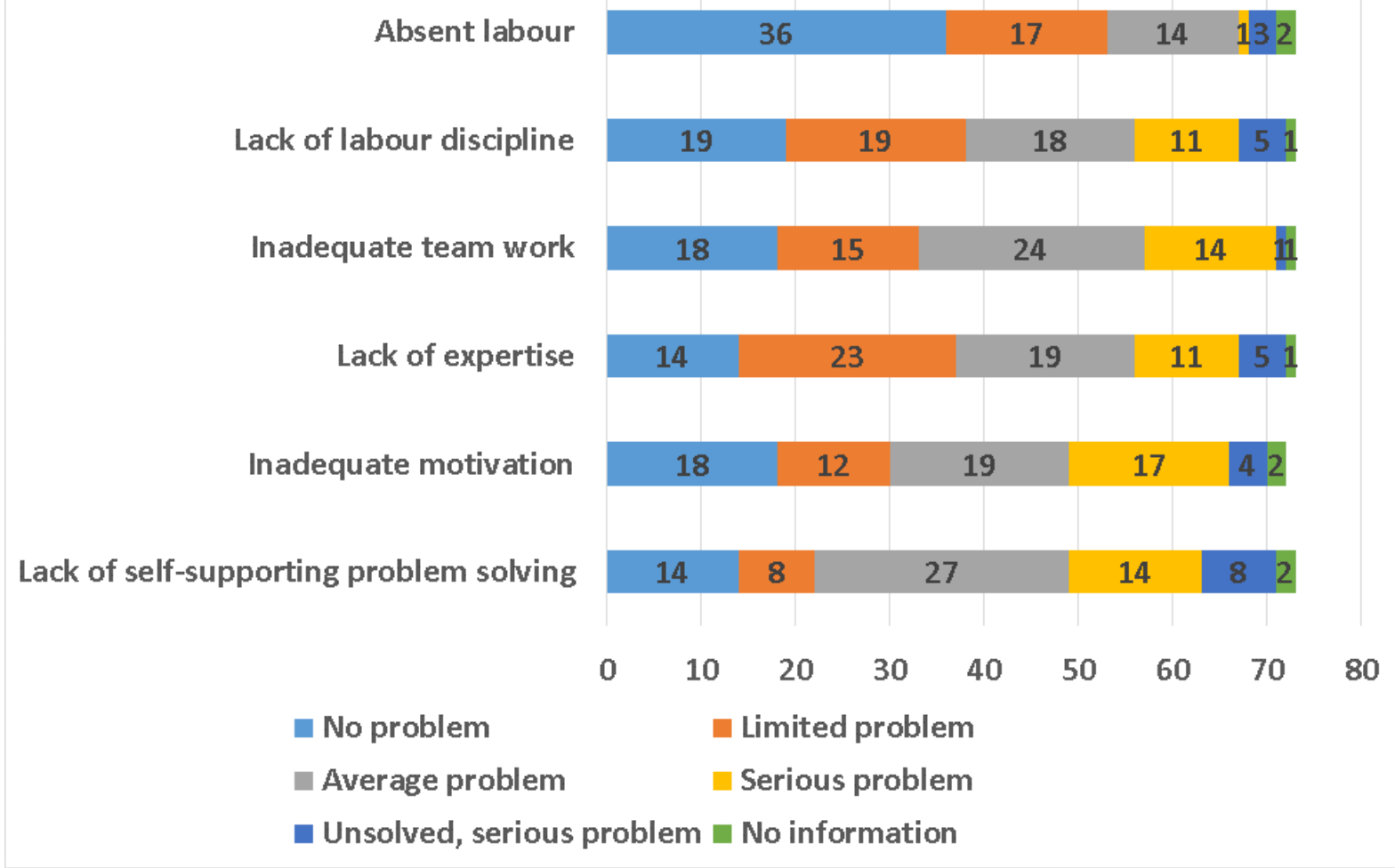

Source: (Bozsik et al., 2020)

The respondents evaluate the importance of each of the sources at a 5 points Likert-scale. (no problem -1 ; limited problem -2 ; average problem -3 ; serious problem -4 and unsolved problem -5) The weighted average of the answers was calculated, where the weights were the number of answers in each category. To calculate the ranking, we took the weighted average of the total answers and ranked them in ascending order, so the less important problem is at the top, while the most important one is at the bottom.

If we look at the rank of the problem (from less important to vital importance in ascending order), the most serious problems are caused by the improperly skilled work force.

1. Lack of self-supporting problem solving - first on the list. So, the manager should precisely instruct the employee, what, when and how should be made. 
2. Inadequate motivation - second on the list, which also highlight the role of the direct control. The daily job of the employees should be carefully planned, and the implementation of the execution should be almost continuously checked. Without continuous control, the employees tend to make nothing or to make very little progress.

3. Lack of expertise - third on the list. The main aim of the state subsidy is to help the people to transfer from the long-lasting unemployment or public work status to a marketable employment. But the answers to this question indicated, that this transformation is not an easy job. To improve the quality of available work force requires the constant supervision of the management and the targeted training of the employees to satisfy the labour market requirements.

The latter aspects like inadequate teamwork, or lack of discipline were qualified as serious or vital problem by the minority of the respondents. The majority declared them insignificant or small problem. The absent labour seems to be a non-relevant issue, since the employees of the social cooperatives earn the minimal wage (161000 HUF in 2020 - about $€ 450)$, which is now almost the double size than the public worker general wage (81 530 HUF in 2020 - about $€ 230$ ). Consequently, to be an employee in a social cooperative is a big jump compared to the public worker status, so there is a strong incentive to keep this job.

The condition of granting state subsidy is the employment of the dedicated employees, so if the social cooperatives dismiss an employee, a new one should be taken. Considering the fact, that these social cooperatives are mostly operating in small settlements (see table 1), to find new employees replacing the improper ones are very hard task.

The other managerial issues have got less significance, as we see in figure 2.

Figure 2: Significance of marketing and technological issues in the management of social cooperatives

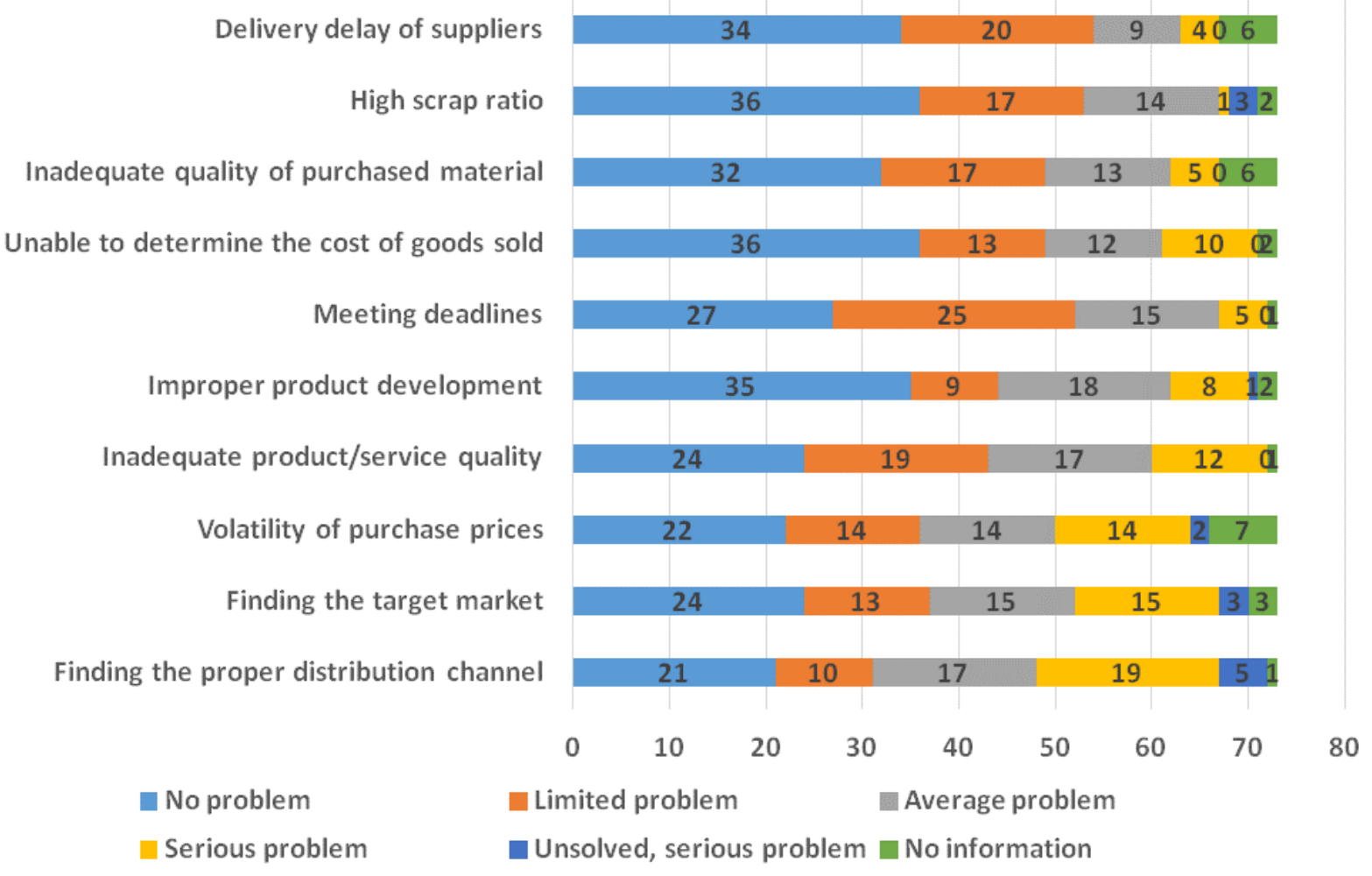

Source: (Musinszki et al., 2019) 
As we can see here, the marketing issues were evaluated more serious (distribution channel, target market, purchase price), the technical problems are less important like scrap ratio or product development).

The reason of it is, that the social cooperatives mostly work up local raw materials and selling them in short distance markets. Considering the fact, that they are new organisations and definitely small ones (see on table 1), their brand strength is very limited. But they cannot compete with prices, because the cost of operation is high due to the improper work force and the limited size of production. To break out from this trap requires proper business cases and perfect implementation of business plans.

The last operating examined problem group was related to the administrative work. This seems the less problematical part of the social cooperative operation.

Figure 3: Significance of administrative issues in the management of social cooperatives

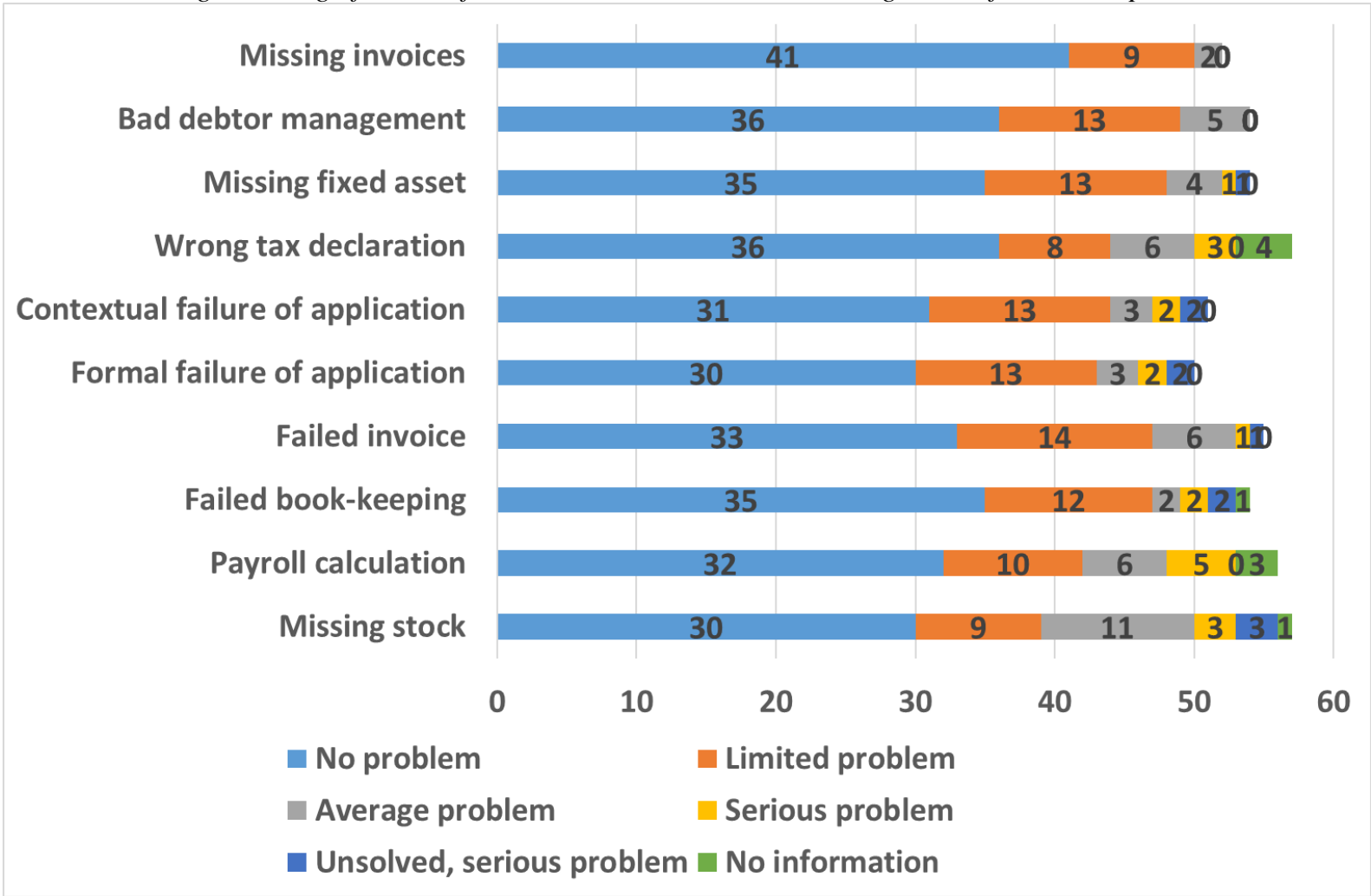

Source: own editing

As you can see, none of the above administrative issues were considered serious or unsolved problem by the tenth of the respondents. The reason is, that the supervisory body of social cooperatives regularly monitor the bookkeeping and the payroll records to ensure the compliance with the requirements of subsidies. Furthermore, the OFA prescribe regular further training programs for the managers and the social cooperatives can apply for employing external specialist. A separate question was devoted to ask the nature of employing external specialist.

The external specialist worked mostly administrative work, two fields can be highlighted, the book-keeping and the application writing. One bookkeeper can manage several socialcooperatives and together with the OFA professional support, the administrative problems can 
be handled. The application writing is also a complex duty, since the majority of the supportive programs are financed directly or indirectly by European Union funds.

The distribution of the response was the following:

Figure 4: Managerial areas for applying external specialist

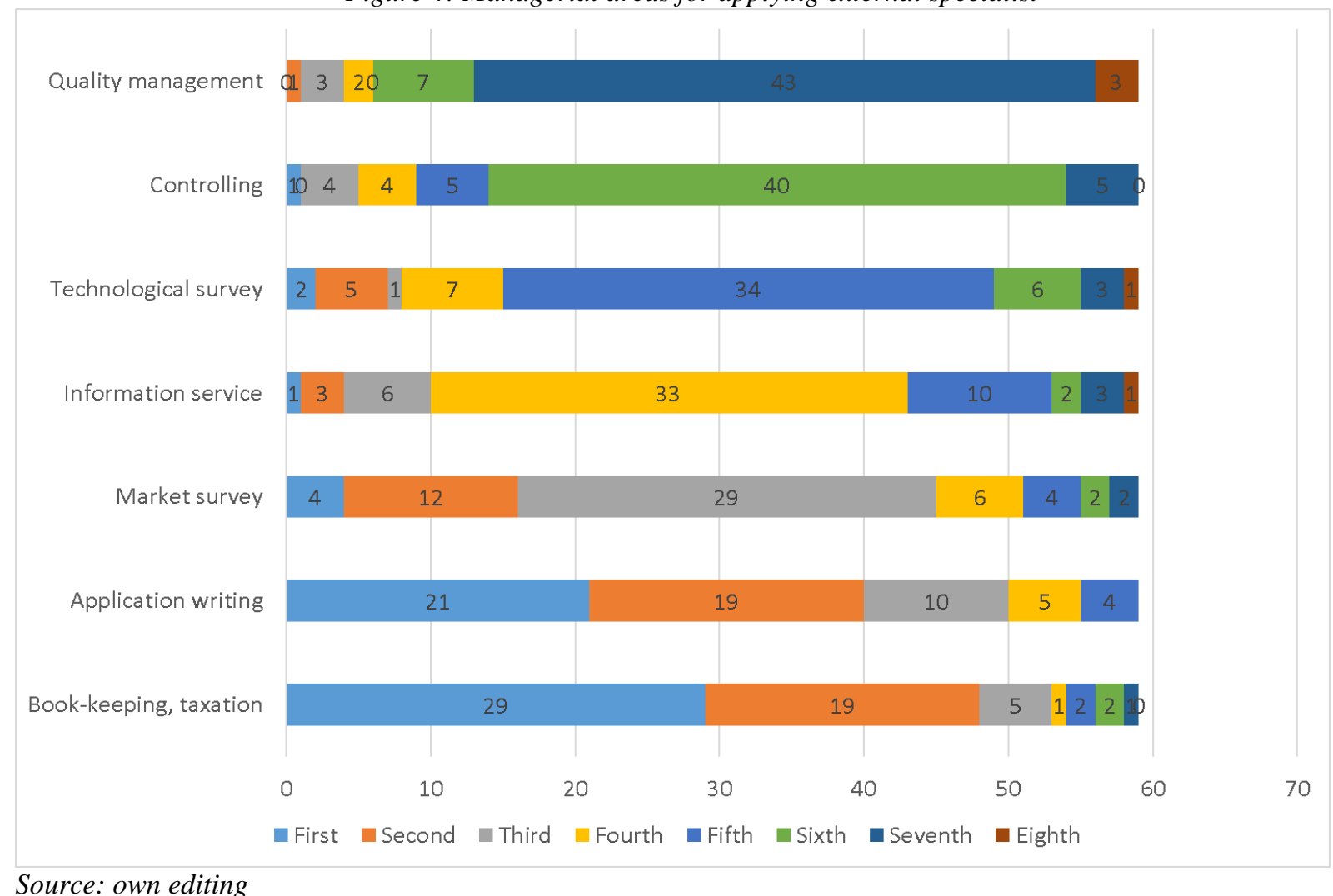

To sum up, the Human Resource Management is the most important challenge, against which the management of the social cooperative is facing. So, to give proper tools in the hand of management to monitor and analyse the labour force performance is vital both to comply the requirements of state application and to survive in a market environment.

\section{Conclusions}

I It can be stated that with the increase of social and territorial disparities, the strongest social enterprises are not necessarily located in the most disadvantaged groups and peripheral areas, these conditions are stronger in the more developed areas. At the same time, more and more social ideas are being transformed into social entrepreneurship. For the social cooperatives need a correct methodology for measuring the human resources.

As we can see from the questionnaire, the Human Resource Management plays a vital role in the social cooperative's management.

One of the tools to support leaders is the balanced scorecard (BSC). The BSC is a balanced, performance indicators-based strategic evaluation system. The viewpoints of the basic model (financial, customer, internal processes, learning and growth) are looking for answers for four questions:

- What are the expectations of the owners? 
- What kind of achievement is expected by the customers?

- In which processes is it necessary to provide outstanding performance?

- How may the change and developmental ability be maintained in the future?

The model assigns objectives, measures, targets and initiatives to each viewpoint. Based on the PDCA principle, the indicators are continuously measured and evaluated. The processes of collecting, reporting, and distributing balanced scorecard information can be labour-intensive. This cannot be solved by an SME, especially a non-profit organization. We want to avoid this problem. Therefore, we want to use the existing data assets of the social cooperatives.

Our future aim to develop a controlling system to monitor and to observer the current state and the development of labour force in a social cooperative. The proposed managerial control system consists of two parts. A table structure will be developed to fulfil the requirements of the reporting system determined by the regulatory authority. A ratio analysis tools will be implemented to analyse the current state and the development of labour force.

\section{Acknowledgement}

This research was supported by the project no. EFOP-3.6.2-16-2017-00007, titled Aspects on the development of intelligent, sustainable, and inclusive society: social, technological, innovation networks in employment and digital economy. The project has been supported by the European Union, co-financed by the European Social Fund and the budget of Hungary.

\section{References}

Bartha Z., and Bereczk Á. (2018) "A társadalmi vállalkozások sikertényezői, erősségei és gyengeségei." In Vállalkozásfejlesztés a XXI. században pp. 6-20.

Borzaga, C., and Defourny, J. (2004) The Emergence of Social Enterprise Routledge.

Bozsik S., Szemán J., Musinszki Z. (2020) “The Role of Human Resource Management Indicators in Social Enterprises with Special Regard to the Social-Cooperatives" European Journal of Social Sciences 3. : 2. pp. 60-75. , 16 p. DOI: 10.26417/ejss.v3i2.p60-75

Defourny, J., and Nyssens, M. (2012). "The EMES Approach of Social Enterprise in a Comparative Perspective". EMES European Research Network. Vol. 12:3 pp. 512-523

Fenyves V. (et al.) (2019) "The Role of the Notes to the financial statements in corporate decision-making" Corporate ownership and controls Vol. 15:4 pp. 138-148.

G. Fekete, É., Hubai, L., Kiss, J., Mihály, M. (2017). "Social Enterprise in Hungary" ICSEM Working Papers, No. 47. The International Comparative Social Enterprise Models (ICSEM) Project.

G. Fekete, É., Lipták, K., Osgyáni, G., Simkó, J., Siposné Nándori, E. (2014a). Lokális foglalkoztatáspolitika, a nem piaci foglalkoztatás jellemzői. ÉMORKA.

G. Fekete É., Nagy Z., Lipták K., Kiss J. (2018). Szociális és szolidáris gazdaság a posztszocialista perifériákon. Bíbor Kiadó.

G. Fekete, É., Vincze, M., Hámori, G. (2014b). A map of social enterprises and their ecosystems in Europe - Country Report: Hungary. European Commission.

G.Fekete É. (2017). "A térsadalmi gazdaság posztszocialista sajátosságai Kelet-KözépEurópában." Közép-Európai Közlemények, Vol. 10:1 pp. 59-74. 
Katonáné Kovács, J., Varga, E., Nemes, G. (2017). "Fókuszban a társadalmi innováció folyamata a magyar vidéken" Észak-magyarországi Stratégiai Füzetek Vol. 14:1, pp. 6-19.

Kawano, E., Masterson, T. N., Teller-Elsberg, J. (2010). Solidarity Economy I: Building Alternatives for People and Planet. Papers and Reports from the 2009 U.S. Forum on the Solidarity Economy. Center for Popular Economics.

Kuti, É. (1998). Hívjuk talán nonprofitnak. A jótékonyság, a civil kezdeményezések és az állami keretböl kiszoruló jóléti szolgáltatások szektorrá szervezödése. Nonprofit Kutatócsoport.

Laville, J.-L. (2010a). "The Solidarity Economy: A Plural Theoretical Framework" Economic Sociology Vo.11:03 pp. 25-32.

Laville, J.-L. (2010b). "The Solidarity Economy: An International Movement" RCCS Annual Review, Vol. 2. https://doi.org/10.4000/rccsar.202

Mückenberger, U. (2018). Rethinking the concept of the "employee" in the age of digitalisation. A New Relationship Between Work and Legal Protection (Vol. 113). Hans Bückler Stiftung.

Musinszki Z, Szemán J., Bozsik S., (2019) “A társadalmi vállalkozások balanced scorecard rendszerének kialakítása a szociális szövetkezetek példáján - pénzügyi mutatószámok" Beyond Financial Reporting Nemzetközi Számviteli és Pénzügyi Konferencia $B G E P S Z K 7^{\text {th }}$ of November 2019

Musinszki Z., Süveges G. "The role of financial indicators in supporting strategic decisions" In: Alina, Badulescu (szerk.) Emerging Markets Economics and Business. Contributions of Young Researchers Oradea, Románia : Oradea University Press, (2018) pp. 247-250. , p. 4

Németh, L. (2012). A szociális szövetkezetek jellemzői és tényszerü adatai Szövetkezés Vol. 33:1-2 pp. 136-145.

Nyssens, M., and Defourny, J. (2008). "Social enterprise in Europe: Recent trends and developments" EMES European Research Network Vol. 08:01

OFA. (2016). Fókuszban az önkormányzati tagsággal rendelkezö szociális szövetkezetek támogatási program. http://palyazatok.org/wpcontent/2016/07/Palyazati_felhivas_utmutato.pdf

Salamon, L. M., \& Anheier, H. K. (1997). Defining the Nonprofit Sector: A Cross-national Analysis. Manchester University Press.

Szemán, J., Musinszki Z., Bozsik S. (2020) “A társadalmi vállalkozások Balanced Scorecard rendszerének kialakítása a szociális szövetkezetek példáján - külső szervezetek igényeinek való megfelelés" Intertantional Journal of Engineering and Management Sciences 5 : 1 pp. 300-317. , 18 p. DOI: 10.21791/IJEMS.2020.1.26 